\title{
Kernos
}

Revue internationale et pluridisciplinaire de religion grecque antique

$10 \mid 1997$

Varia

\section{Death and Afterlife in Minoan Religion}

\section{Bernard C. Dietrich}

URL: http://journals.openedition.org/kernos/643

DOI: 10.4000/kernos.643

ISSN: 2034-7871

\section{Publisher}

Centre international d'étude de la religion grecque antique

\section{Printed version}

Date of publication: 1 January 1997

Number of pages: 19-38

ISSN: 0776-3824

Electronic reference

Bernard C. Dietrich, « Death and Afterlife in Minoan Religion », Kernos [Online], 10 | 1997, Online since 12 April 2011, connection on 30 April 2019. URL : http://journals.openedition.org/kernos/643 ; DOI : 10.4000/kernos.643 


\section{Death and Afterlife in Minoan Religion}

Minoan religion centred on the fruitfulness of nature and its powers of renewal. Death was a necessary stage of that process to ensure rebirth. Did the Minoans or Mycenaeans, for that matter, look beyond that recurring cycle of life from death? Burial practices do not contribute any decisive information on this point. The mode of disposal of the physical remains had little bearing on religious belief: cremation or burial served the same purpose and had no particular significance in what was thought to happen after death. Nor did either method fundamentally affect the nature of funerary ceremonial ${ }^{1}$. In such a pragmatic vision of death as a natural stage in the repeating cycle of renewal there is little room for concepts of afterlife. The belief in a continued separate existence in some otherwordly fourth dimension presupposes the notion of survival in some form of individual identity after death. Minoan and Mycenaean iconography is not helpful on that point, or at best ambiguous.

A terracotta model, that was found in the tholos complex at Kamilari, consists of two pairs of figures sitting against the wall of a portico and receiving offerings of food from two smaller male figures who stand before them ${ }^{2}$ (Fig. 1). The setting recalls the scene on one of the long sides of the Hagia Triada sarcophagus, where the statue-like main figure of the dead is being offered various gifts $^{3}$. Both representations are instances of a special service for, tendance of, or more likely cult of the dead. The extended festival, that is depicted on the sarcophagus, includes sacrifice in honour of the dead, gifts and libations. All of those were common on such occasions from the early funerary cults about the tombs in the Mesara ${ }^{4}$. Underlying the 'celebration' of death with its elaborate ritual, which also included communal meals, is the expectation of renewal.

1 E. Vermeule, Aspects of Death in Early Greek Art and Poetry (Sather Class.Lect. 46), Berkeley, 1979 (Sather Class, Lectures, 46), p. 2; B. UHDE, Psycbe. Ein Symbol?, in G. STEPHENSON (ed.) Leben und Tod in den Religionen. Symbol und Wirklicbkeit, Darmstadt, 1980, p. 112.

2 D. LEVI, La Tomba a Tbolos di Kamilari, in ASAA, 39/40 (1962), p. 59. The roof crowned with horns of consecration is now missing.

3 Recent discussions of the larnax with full bibliographies are by W. POTSCHER, Aspekte und Probleme der Minoiscben Religion. Ein Versuch, Hildesheim-Zürich-New York, 1990, p, 171-191; N. MARINATOS, Minoan Religion. Ritual, Image, and Symbol, Univ. South Carolina Press, 1993, p. 3136; 254 n. 113.

4 K. BRANigan, The Tombs of Mesara, London, 1970; E. VERmEule, Greece in the Bronze Age, Chicago, 1966, p. 44 . 
Despite the often precious gifts, there is no convincing evidence that the funerary cult implied heroization, or indeed deification, of the dead ${ }^{5}$. Hero cult has plausibly been explained as a phenomenon of archaic times in the main, and it tended to be reserved for Homer's warriors before Troy, or for the heroes that were thought to have been buried in prehistoric Mycenaean tombs ${ }^{6}$. The recurring rites in honour of the dead focused on the tomb rather than on one individual among the many dead that were buried there ${ }^{7}$. Exceptions to the rule are conceivable in the case of extraordinary royals or noblemen, including the person who had been buried in the Hagia Triada sarcophagus. It is of considerable interest that important aspects of funerary ritual changed little, if at all, between the Bronze Age and classical times. The actions of tending the dead, laying out of the corpse (prothesis), signs of mourning and so on remained very similar, apart from 'technical' differences of burial and cremation ${ }^{8}$. Minoan terracottas of mourning women in black dress, with hands clasped over their heads, are virtually identical to their Mycenaean and Greek counterparts ${ }^{9}$. The characteristic gesture of mourning is repeated on Mycenaean coffins, and it is quite familiar in geometric and archaic Greek art ${ }^{10}$.

\section{Phourni: Minoan/Mycenaean funerary cult}

A walled off area with seven Mycenaean shaft graves in the Minoan cemetery of Phourni at Arkhanes in Crete looks like an implant in foreign soil. The mode of burial, however, suggests an affinity between Minoan and Mycenaean practice $^{11}$ (Figs. $2 \& 3$ ). In many respects the setting resembles that of Grave Circle A in Mycenae, although it antedated the Phourni enclosure by some two

5 BRANIGAN, op. cit. (n. 4), p. 117; V. LA ROSA, Ancient Crete. A Hundred Years of Italian Arcbaeology 1884-1984, Rome, 1985, p. 142. For a different view of the Kamilari dead see LEVI, art. cit. (n. 2), p. 123; I. PINI, Beiträge zur minoiscben Gräberkunde, Wiesbaden, 1968, p. 29.

6 V.R. d'A. DESBOrough, The Greek Dark Ages, London, 1972, p. 283; J.N. COLDSTREAM, Geometric Greece, London, 1977, p. 164; A. SNODGRASS, Archaic Greece. The Age of Experiment, London, 1980, p. 39; B.C. DIETRICH, Death, Fate and the Gods, repr. London, 1967, p. 31-35. The chthonic cult of heroes (daemons) in popular belief and superstition is discussed on p. 35-58. There are a number of different theories regarding hero cult vis à vis tomb and ancestor cult in the Early Iron Age and archaic Greece. They have most recently been critically discussed by Carla $M$. ANTONACCIO, The Archaeology of Ancestors: Tomb Cult and Hero Cult in Early Greece, London, 1995.

7 Opinions differ on this point, see the previous note and Carla ANTONACCIO, Placing the Past, in S.E. AlCOCK, R. OSBORNE (eds.), Placing the Gods, Oxford, 1994, p. 90-92.

8 VERMEULE, Aspects, op. cit. (n. 1), p. 63.

9 Cf. Gth century B.C. Attic b-f bowl with mourning women, VERMEULE, Aspects, op. cit.(n. 1), Fig. 19.

10 E.T. Vermeule, Painted Mycenaean Lamakes, in JHS, 85 (1965), p. 142; Pl. xxv (a)(b); xxvii A, B, C, D; Aspects, op. cit.(n. 1), p. 12-14, 6th cent. vase, Fig. 7.

11 On the cemetery of Phourni, which was in use for over 1000 years from EM II - LM IIIC, see J. \& E. SAKELlarakis, Crete. Archanes, Athens, 1991. 
hundred years. But the peribolos wall at Mycenae, which was circular because of the unevenly spaced graves, and the rectangular enclosure wall in the Cretan cemetery were virtually contemporary ${ }^{12}$. The burials themselves present a striking mixture of Minoan and Mycenaean customs: at Phourni the dead had been placed inside Minoan-type larnakes, but the gifts were found directly in the shaft, as in the case of the Mycenae graves which had no coffins. The sides of the larnakes in Phourni had been painted, but those found in situ were mostly broken and empty, except for one which contained a few bones. Indications are that, like their Minoan neighbours, the Mycenaeans there practised secondary burial: after the flesh had rotted away, they exhumed the bones and laid them to rest in the Minoan-type coffin.

The characteristically Minoan terracotta larnax looks like a rounded bathtub or, in another popular shape, like a rectangular chest, commonly with a lid in the form of a pitched roof. Larnakes are known from Early Minoan but became practically universal in post-palatial times in Crete. On the mainland they are rare. A few quite late (13th/12th century B.C.) Mycenaean examples were known; but they were believed to be exceptional and alien to Mycenaean custom, until the relatively recent discovery of about a dozen such coffins in a cemetery at Boeotian Tanagra ${ }^{13}$. The Mycenaean coffins from Phourni now add to the evidence.

Funerary ritual primarily concerned tendance of the physical remains and did not obviously involve awareness of, let alone care for, a soul of the dead ${ }^{14}$. Throughout Greek history the rites of laying out the corpse, carrying it to the place of burial, mourning and so on, constituted important elements of separation of the dead from the living: a guiding away to another stage. In classical times and later, scenes of parting are common on Attic grave monuments. The dead is seen leaving his tomb on white-ground lekythoi, or oil flasks, which were placed with the burial. Hermes guides the dead to the ferryman Charon who takes him to Hades across the Acheron river. Scenes of this nature belong primarily to the 5 th century B.C., and so does the figure of Charon ${ }^{15}$. Descriptions of Hades and its topography first occur in Homer's Odyssey. The two Nekyiai of Books 11 and 24 provided a model on which myth could build up its geography of the underworld ${ }^{16}$.

\footnotetext{
12 Ibid., p. 71.

13 VERMEULE, art. cit. (n. 10), p. 123-148. On the Tanagra larnakes see now also W. CAVANAGH C. MEE, Mouming before and after the Dark Age, in Klados. Essays in bonour of J.N.Coldstream, London, 1995 (BICS Suppl. 63), , p. 45-61.

14 But see VermeUle's discussion in Aspects, op. cit. (n. 1), p. 7-11.

15 Cf. Charun in Etruscan belief and art, DiETricH, Fate, op. cit. (n. 6), p. 147.

16 VERMEule, Aspects, op. cit. (n. 1), p. 4; 211 n. 6. Scenes of the underworld became popular on South Italian r.-f. vases, A.D. TreNDALL, South Italian Vase Painting, BM, 1966, p. 12-13.
} 


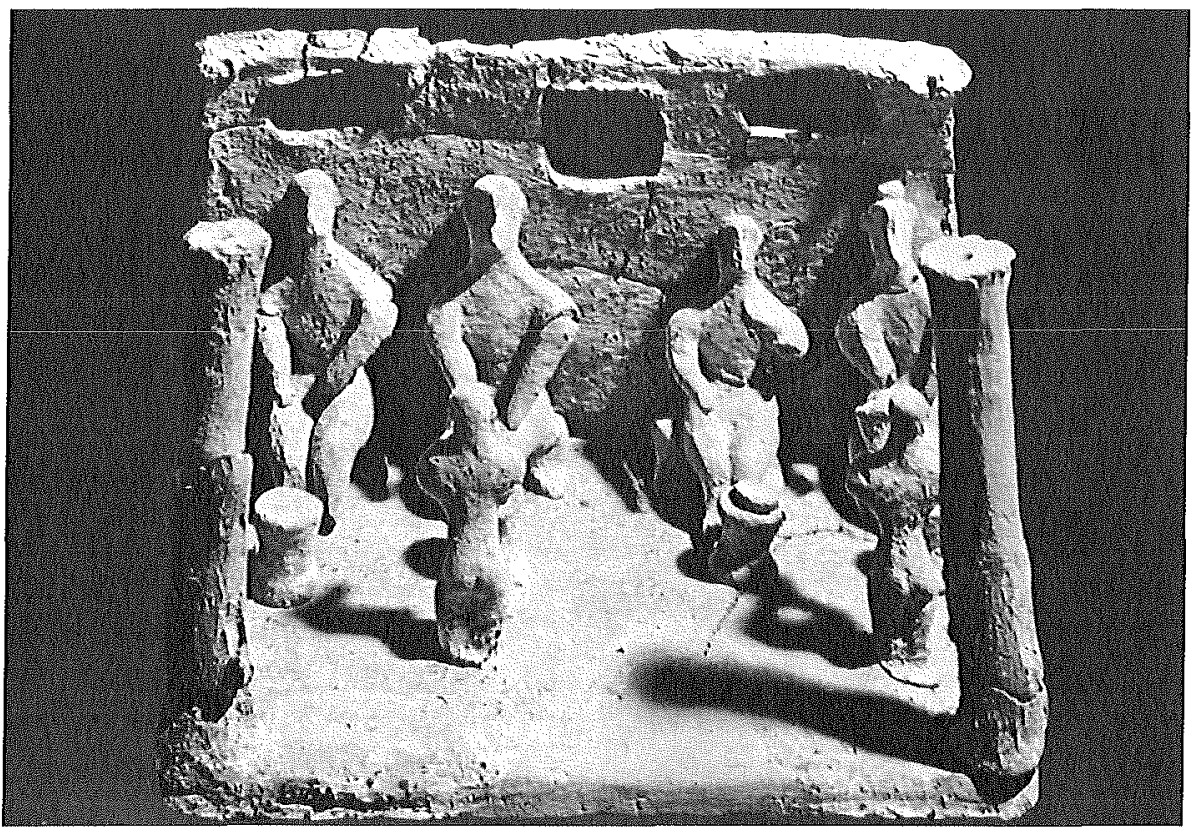

Fig. 1 : Terracotta model from Kamilari

(I. SAKELlarakis, Guide to the Heraklion Museum, Athens, 1979, p. 54 [lower])

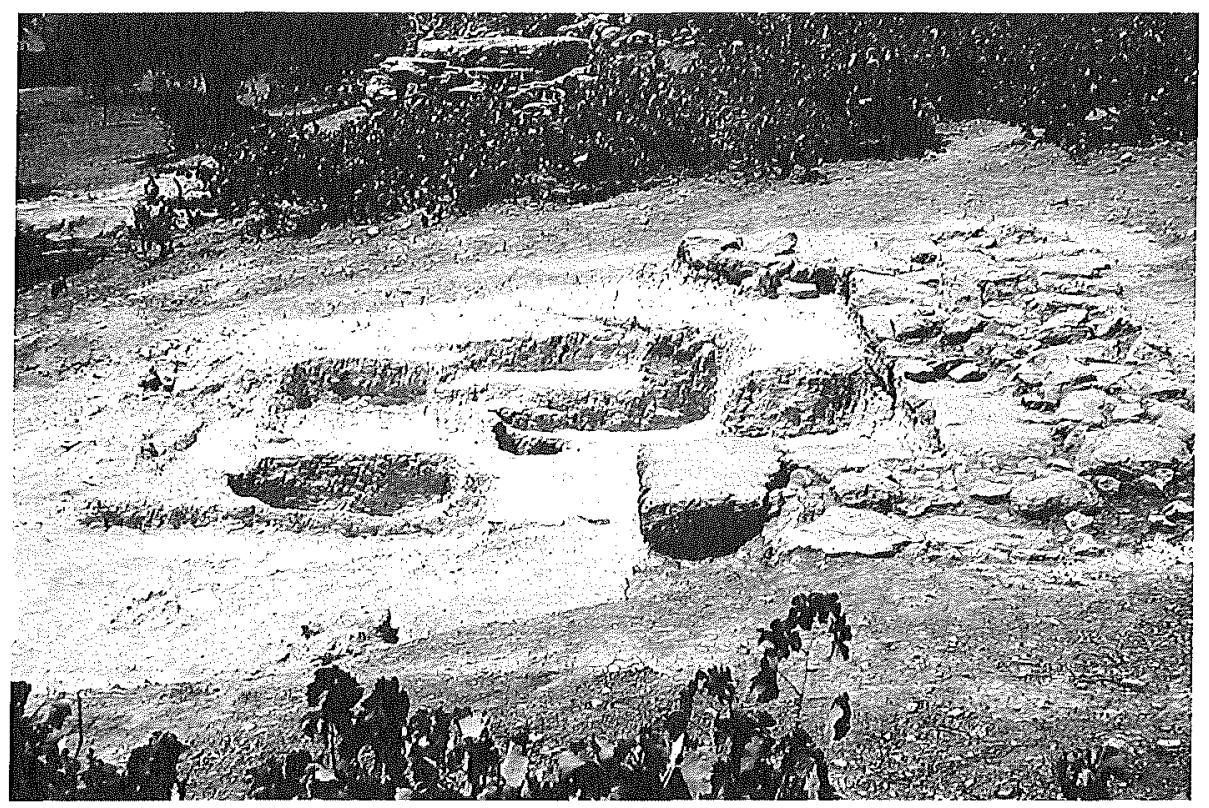

Fig. 2 : Mycenaean Shaft Graves, Phourni, Crete

(J. SAKLELlarakis, Crete, Archanes, Athens, 1991, fig. 41) 


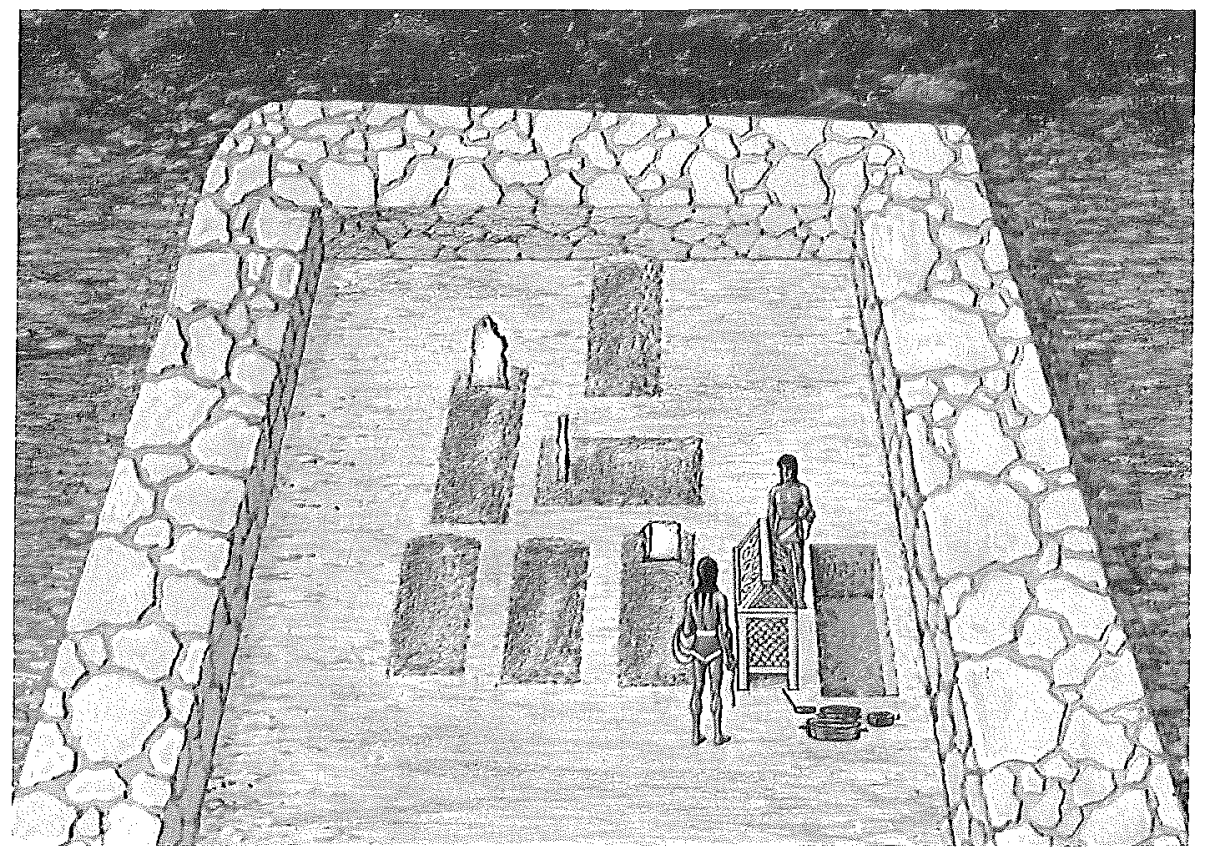

Fig. 3: Mycenaean Shaft Graves, Phourni, Crete (Reconstruction)

(j. Saklellarakis, Crete. Arcbanes, Athens, 1991, fig. 42)

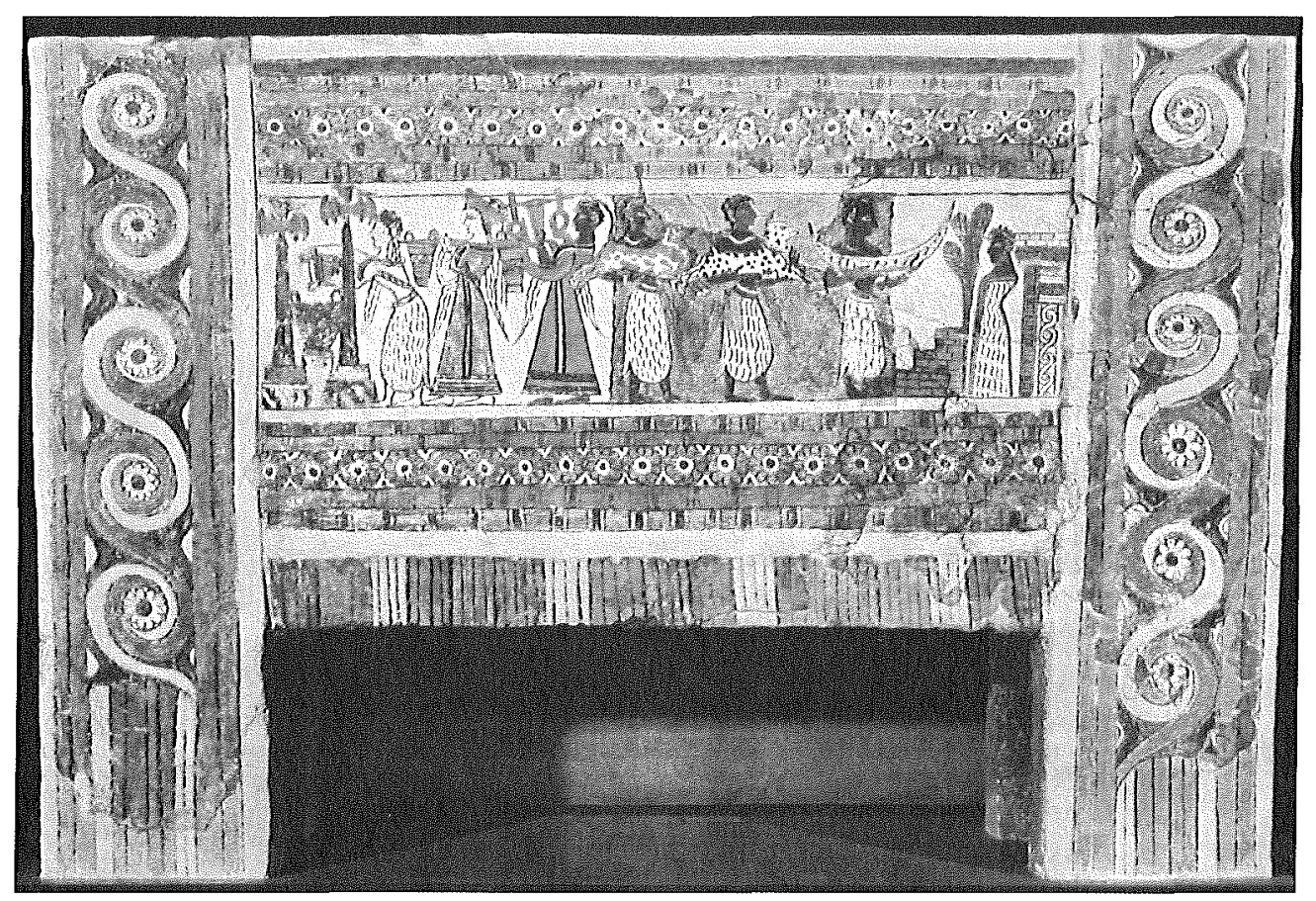

Fig. 4 : The Haghia Triada sarcophagus (MARINATOS-HIRMER, op. cit. [n. 46], pl. XXX). 
Funerary ritual also had a negative function of preventing the return of the deceased's spirit ${ }^{17}$. There is no trace of a belief in an immortal human soul in this practice which simply reveals the powerful atavistic fear that the potentially harmful spirit might return to hurt the living ${ }^{18}$. In popular superstition such evil spirits were daemons, goblins and bogeys in the service of the goddess Hecate. They could assume the shape of birds and strike anyone with madness or disease $^{19}$. Fears of this kind are pretty universal in most cultures, and they doubtless played a part in Minoan and Mycenaean superstition as well ${ }^{20}$.

However, the Minoan common practice of multiple burial in one tomb, and especially of reburial, does not suggest a lasting concern for the dead. The bones of earlier burials were treated with scant respect: they were unceremoniously pushed to one side in order to make room for new additions. Care obviously ended when the corpse's familiar physical features had disappeared. So ideas of any sort of palpable afterlife, are a fortiori unlikely in Minoan religion ${ }^{21}$.

There is a period of transition between death and actual burial or cremation. That period is taken up by the prescribed and basically unchanging rites ${ }^{22}$. The passage grows considerably longer in the case of secondary burial which may take between two to five years after death ${ }^{23}$. It has been suggested that the traditional long period was needed for the soul of the dead person to break free of its earthly bonds ${ }^{24}$. Indeed, similar notions are all but common coinage since the Presocratic philosophers. The doctrine of the body as the tomb of the soul $(\sigma \hat{\omega} \mu \alpha \sigma \hat{\eta} \mu \alpha)$, became familiar through Orphic teaching in the Gth century B.C., and it appealed to subsequent Greek philosophy ${ }^{25}$. The concept depends on a belief in the survival of the individual's soul that was subject to reward or punishment for past sins. Neither is likely, or at least provable, for the world of Minoans and Mycenaeans. The practice of secondary burial did not by itself indicate any eschatological ideas but allowed the living, who remained behind, to take proper leave of their dead.

17 DETLEF - I. LAUF, Im Zeichen des grossen Übergangs, in Leben und Tod in den Religionen, Darmstadt, 1980, p. 88.

$18 C f$. the banning of spirits of the dead (Keres) at the end of the Anthesteria festival, M.P. NILSSON, GGRI I , p. 222, 597; DIETRICH, Fate, op. cit. (n. 6), p. 241.

19 Refs. in E. ROHDE, Psycbe (repr. of 8th ed., transl. by W.B.Hillis), London, 1950, App. VII, p. 593594; ANDRES in RE Suppl. III, s.v. Daimon; M.P. NILSSON, Griecbiscbe Feste von Religiöser Bedeutung mit Ausscbluss der Attiscben, Leipzig, 1906, p. 396; DiETRICH, Fate, op. cit. (n. 6), p. 18-20, 241-242.

20 See DIETRICH, Fate, op. cit. (n. 6), p. 144-145.

21 Above n. 5.

22 Vermeule, Aspects, op. cit. (n. 1), p. 2.

23 MARINATOS, MinRel, op. cit. (n. 3), p. 26-27.

24 lbid.

25 The idea was taken up by PLATO, Crat., 400c; cf. Gorgias, $493 \mathrm{c}$ with other etymologies of the two words. See also ROHDE, Psycbe, op. cit. (n. 19), p. 335-361; W. BURKERT, Greek Religion. Archaic and Classical (transl. by J.Raffan), Oxford, 1985, p. 322. 


\section{The concept of Elysium and Minoan eschatology}

Yet, sunt aliquid manes, letum non omnia finit. "There are such things as shades, death does not end all', according to Propertius ${ }^{26}$. At the moment of death something deserts the body which stays unmarked but begins its process of disintegration. 'Soul' is a convenient term for this essential element of life. Homer calls the insubstantial life-breath $\psi v \chi \eta^{\prime}$ ( $p s y c h e$ ) which literally means just that, 'breath' or 'air' 27 . In epic the dying hero first loses his $\theta v \mu$ '́, that is his physical living strength, which leaves the body and vanishes. The yoxń follows his $\theta u \mu$ ó but does not dissolve: it flies away dream-like ${ }^{28}$. It flutters like a bat on its way to Hades, after the physical remains have been duly buried ${ }^{29}$. $\Psi u x \eta ́$ in Homer means 'life' therefore and not 'soul; even animals possessed a $\psi v \chi \eta$ ' which they lost at death ${ }^{30}$.

A hero's psyche, however, entered Hades, 'Aïns in Homer, namely a personification of 'the Invisible', which is an appropiate term for the abode of

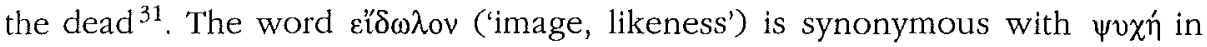
Homer: the eidolon gave visible form to the latter which in epic belief was concept more than shape. The 'image' allowed the dead hero to appear physically in his former shape but on a much smaller scale, waif-like and with wings fluttering about gloomy Hades. The winged eidolon, which has been compared with a soul-bird ('Seelenvogel'), became a popular theme for Greek vase painters from the 8 th $/ 7$ th to the 5 th century B.C. They pictorially realised Homer's vision of a man's psyche and its eidolon ${ }^{32}$. Aristotle was the first authority to use psyche in the sense of 'butterfly' or 'moth'33.

The soul is still pictured as a butterfly in the folklore of modern Crete and other peoples ${ }^{34}$, bringing together an ancient symbol of the renewal of life and philosophical / moral ideas of an immortal soul ${ }^{35}$. Homer's shades (psychai)

\footnotetext{
26 PROP., IV, 7, 1.

27 NILSSON, GGR $\mathrm{I}^{3}$, p. 192-199, especially p. 194. On the Homeric concept of life, soul and afterlife see also ROHDE, Psycbe, op. cit. (n. 19), p. 3-43; E. BICKEL, Homeriscber Seelenglaube (1925); J. BÖHME, Die Seele und das Ich im Homeriscben Epos (1929); B. SNELL, Die Entdeckung des Geistes (1975); B. UHDE, art. cit. (n. 1), p. 103-117; A. DIHLE in Festschrift Stuiber, JJAC, 9 (1982), p. 9-20; BURKERT, GrRel, op. cit. (n. 25), p. 194-199.

28 Od., XI, 222.

29 Od., XXIV, 5-7; cf. EUR., Hecuba, 705.

30 Od., XIV, 426.

31 On this likely etymology see NILSSON, GGR ${ }^{3}$, p. 455.

32 Homer borrowed his familiar notion from an earlier source, VERMEULE, art. cit. (n. 10), p. 146-147; see below n. 40. On the popular idea of a soul-bird, see G. WEICKER, Der Seelenvogel (1902) who collected the relevant instances; NILSSON, GGR $\mathrm{I}^{3}$, p. 197-199.

33 Hist. an., 551a 14.

34 A. EVANS, The Palace of Minos at Knossos, London, 1921-1935 (cited PM below) III, p. 151.

35 B.C. DIETRICH, The Origins of Greek Religion, Berlin, 1974, p. 121-122.
} 
were, and always remained, insubstantial. They lacked strength, except temporarily after drinking the blood of freshly slaughtered victims, as in the Nekyia of Odyssey 11, and they had no hope of ever being reborn. The psychai languished miserably in Hades for all time, so that even Achilles' shade was moved to complain to Odysseus, that he would rather be a serf in the world above than king of all the shades below ${ }^{36}$. Homer perceived Hades' realm as existing in parallel with the world of the living; the psychai continued in Hades as replicas of their old selves in occupation and social position but without punishment or reward for their former deeds. The underworld in fact was modelled on the world of the Olympians. In Homer Phoenix describes Hades as the 'chthonic Zeus ${ }^{37}$. Hades ruled his lower realm but also lived in a palace just like the Olympians $^{38}$.

The epic mythological and geographical details of Hades contain contradictions which arose as a result of foreign influence impinging on earlier tradition. Hades is imagined as below the ground in a subterranean underworld, or at the edge of the world and beyond Oceanus. In a passage from the Second Nekyia Hermes leads the psychai of the dead suitors past the White Rock and the Gates of the Sun, the Land of Dreams and on to the Field of Asphodel, 'where dwell the psychai, shapes (eidola) of men outworn' ${ }^{39}$. These are colourful, poetic variations on the basic theme of human psycbai and their visible eidola. The idea is older than Homer's poem, old enough to reach back to the myths of post-palatial Crete and the Greek mainland ${ }^{40}$.

Few neopalatial burials are known in Crete and practically no clearly identifiable funerary imagery ${ }^{41}$. However, paintings of sea creatures on the sides and even inside Minoan coffins (larnakes) at the end of the period have led to the suggestion that Minoans buried their dead at sea, thus accounting for the strange archaeological lacuna ${ }^{42}$. The idea of an island- sea-faring people sending their dead on their last voyage across the sea, is certainly attractive. It conjures up Hesiod's Isles of the Blest ${ }^{43}$ and agrees with Egyptian practice ${ }^{44}$. Some, but by

36 Od, XI, 489-491.

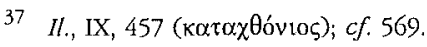

38 NILSSON, GGR $\mathrm{I}^{3}$, P. $452-456$.

39 Od., XXIV, 11-14, see A. HEUBECK's comments on the passage in A Commentary on Homer's Odyssey, Oxford, 1992, p. 360-361; cf. BURKERT, GrRel, op. cit. (n. 25), p. 196.

40 See n. 32 .

41 PINI, op. cil. (n. 5), p. 52-54; MARINATOS, MinRel, op. cit. (n. 3), p. 229.

42 NILSSON, $M M R^{2}$, p. 625-626; MARINATOS, MinRel, op. cit. (n. 3), p. 231.

$43 W E D, 170-173$. The concept of Elysium is discussed in a forthcoming study on Minoan religion. The topic has been densely argued by Chr. SOURVINOU-INWOOD in her book 'Reading' Greek Deatb. To the End of the Classical Period, Oxford, 1995, p. 32-56. Her conclusions regarding the non-Minoan origin of Elysium basically agree with mine.

44 See n. 42 . 
no means the majority of, Minoan cemeteries were placed near the sea, in eastern Crete for example and in the north at Mallia.

Furthermore, models of boats have been found in Minoan tombs, perhaps for this very purpose ${ }^{45}$. One also thinks of the offering of a boat to the deceased on one of the long sides of the Hagia Triada sarcophagus ${ }^{46}$. Some Minoan larnakes were made in the shape of boats, but they would sink instantly if launched on the sea. Others look like bathtubs or boxes, that is practical containers and quite unsuitable for crossing the sea to another world ${ }^{47}$. Equally remote is the suggestion that the Greek myth of Danae and Perseus, who were set adrift in a box by her father Acrisius, preserved a distant memory of Minoan custom of burial at sea ${ }^{48}$.

One votive model of a boat from a funerary context, and now in the Mitsotakis Collection at Chania, appears to be carrying a large honeycomb. According to one interpretation, the honey was intended as food for the dead on his last voyage ${ }^{49}$. But if it is a honeycomb ${ }^{50}$, a more obvious connection seems to be with the bee as symbol of regeneration ${ }^{51}$. Boats are appropiate gifts to the dead of a seafaring people and keen fishermen.

Chance preserved an important funerary document in the painting on the four sides of the Hagia Triada sarcophagus ${ }^{52}$ (Fig. 4). It has been plausibly suggested that the decoration on the two long sides tells one continuous story of a festival for the dead that extended over more than one day. The style of the pictorial programme is still that of the neopalatial fresco. But the identity of the dead person, who received the gifts and who was honoured by the elaborate ceremonial, has been subject to debate. He may have been a mere mortal of noble or royal blood, or even a heroized dead on his way to another world ${ }^{53}$. One could wish for new Minoan finds to corroborate such a view which is mainly based on Egyptian belief. Two pairs of female figures are seen driving chariots from right to left across the small end panels of the coffin. One chariot

45 D. GRAY, Seewesen, Göttingen, 1974 (Archaeologia Homerica), p. 14-19. For a critical review of the evidence see R. LAFFINEUR, La mer et l'Au-delà dans l'Égée prébistorique, in Agaeum, 7 (1991), p. 233-235.

46 Sp. Marinatos - M. Hirmer, Kreta, Thera und das Mykeniscbe Hellas, Munich, 1976 $6^{3}$, Pl. XXXII, top.

47 Suggested by B. RUTKOWSKI, Kykladen und Kreta: Bemerkungen über die bronzezeitlicbe Religion, in $A A A, 9$ (1976), p. 237.

48 Criticised by LAFFINEUR, ant. cit. (n. 45), p. 234.

49 C. DAVARAS, in $A E$ (1984), p. 76-92; fig. 1 on p. 56.

50 Doubted by LAFFINEUR, art. cit. (n. 45), p. 235.

51 DIETRICH, Origins, op. cit. (n. 35), p. 119-122.

52 See above n. 3. According to SOURVINOU-INwOOD's eccentric view, the frescoes do not show funerary scenes but divine cult in which the figure receiving the offerings represents a priest acting on behalf of a god. ('Reading' Greek Death, op. cit. [n. 43], p. 42).

53 NILSSON, $M M R^{2}$, p. 432-433. 
is drawn by two winged griffins, and the other is apparently harnessed to two goats. Both scenes should most probably be integrated as part of the whole composition and, judging by the syntax of Minoan wall painting, the figures represent goddesses ${ }^{54}$. If true, the ritual, which is depicted on the larnax, would convey a more general significance of the symbolic celebration of death and regeneration.

Since the early days of Minoan studies there has been much confident hope of discovering convincing evidence for a fully developed eschatology in Minoan belief. The primary expectation has been that of an Egyptian-type conception of a paradise for the dead. The Ialu or Earu Fields on an island across the sea, where the blessed souls of the dead continued to exist after death ${ }^{55}$. A memory survived, according to this line of thought, in Homer's Elysian Plain to which Menelaus was destined to be transported after his death, escaping the universal human fate of descending to Hades. The poet also briefly mentions in passing that Rhadamanthys lived there, as if his audience would be expected to $\mathrm{know}^{56}$. The passage contains the only mention of Elysium in both epics. The presence of Rhadamanthys implies a Cretan belief in the existence of a moral judgment of the dead. Indeed, his brother Minos is described in the Odyssey as judging the shades in Hades ${ }^{57}$.

There is an important distinction here, though, because in performing that function in Homer's Hades the king did no more than continue his characteristic activity in this life. In the same way the three great sinners of Greek mythology, Tantalus, Sisyphus and Tityus, go on with their regime of penance even in Hades $^{58}$. More advanced moral notions came later. The idea of judgment of dead souls on their conduct in this life was probably not formulated in Greece before the 6th century B.C. under influence of Pythagorean and Orphic thought. Plato first described Rhadamanthys' office as judge of the dead ${ }^{59}$. Homer's Elysium (Od. 4, 563-564) is not mentioned again in Greek literature before the Argonautica by Apollonius of Rhodes ${ }^{60}$. It is unique, like the scenes on the Hagia Triada sarcophagus, and it furthermore clashes with the picture of murky Hades which was the more familiar fate of mortals in the western Aegean ${ }^{61}$.

54 Whether the goats are pulling two chthonic goddesses is another question, MARINATOS, MinRel, op. cit. (n. 3), p. 35-36. See also PÖTSCHER, Aspekte, op. cit. (n. 3), p. 181-182.

55 E.g. NLLSSON, $M M R^{2}$, p. 626-627; GGR I ${ }^{3}$, p. 693; VERMEULE, Aspects, op. cit. (n. 1), p. 72-73, with detailed references.

56 Od., IV, 561-564.

57 Od., XI, 568.

58 NILSSON, GGR $\mathrm{I}^{3}$, p. 454.

59 Apology, 41a; Gorgias, 523e.

$60 A R, \mathrm{IV}, 811$.

61 See n. 43. 


\section{The 'Ring of Nestor'}

Sir Arthur Evans digresses to describe the discovery of a remarkable ring in a tholos tomb at Pylos (Kakovatos). The solid gold signet was found by a peasant in 1907 before the first German excavations at the site. Evans went out of his way to acquire the object after seeing an impression of the design ${ }^{62}$. He called it the 'Ring of Nestor' after the king of Messenian Pylos, where the ring had been discovered (Fig. 5). Going by the associated painted pottery in the same tomb, Evans dated the ring to the first phase of the Late Minoan period, that is about the second half of the 16 th century B.C. ${ }^{63}$. It is a little earlier therefore than the Hagia Triada sarcophagus and its decoration very much in the style of the Knossian Miniature Frescoes ${ }^{64}$. There are 17 figures, human and animal, in the ring's design without counting the two lepidoptera in the top-left zone. They greatly outnumber those of any other known ring of the Minoan and Mycenaean repertoire. In dress, actions and accoutrements the figures are strictly Minoan, although there is an impression of separate elements or groups having been placed side by side without perhaps fully coming together in one organic composition. The field of design on the bezel is dramatically divided into four separate zones by the trunk of a gigantic tree which, together with its horizontal branches, extends to the north, south, east and west edges of the oval ring. Like Yggdrasil, the Scandinavian 'Tree of the World', the top of the trunk here touches the sky, while its massive roots reach deep down below the surface to the netherworld ${ }^{65}$.

The first scene on the top left shows a seated pair of female figures next to a standing young male and woman with raised arms. Above the larger, seated female, whom Evans identifies as the Minoan Great Goddess, two butterflies are hovering with two chrysalises still higher up in the same field. A large couchant lion, symbol of royal and divine power, has his head turned to the right and all but fills the other upper zone. He is lying on a platform, which Nilsson identifies as a sacrificial table like that on the Hagia Triada sarcophagus. On the ring, however, the table is more elaborate: it has two top plates and what look like three portable altars with incurving sides for legs. Also two figures are shown kneeling before the massive platform ${ }^{66}$.

The left lower field suggests the typical progress of a procession with the leading figure drawing the three others to the right towards the tree. On the other side are three bird-headed females of which one is turned to the left as if

\footnotetext{
62 PM, III, 145-157, Fig. 95; 104; Pl. XXA.

$63 P M$, III, 146.

$64 P M$, III, $146 ; 155 ; 157$, see also NILSSON, $M M R^{2}$, p. 43-45, specially p. 45.

$65 P M$, III, 147-148; NILSSON, $M M R^{2}$; p. 44.

$66 M M R^{2}$, p. 47-48. Nilsson believes the artist revealed his forgery by misunderstanding the correct use for the platform as a slaughtering table.
} 
beckoning to the processional group, while the other two with characteristic gestures of adoration stand before a winged griffin seated on a table. The woman behind the griffin effectively frames the scene. She stands at the right facing inward to the left. She is taller than the adorants and more formally dressed like a priestess or possibly goddess. Her head is disproportionally small in the manner of late neopalatial glyptic ${ }^{67}$, so that it is impossible to see whether her features are human or those of a bird like the other three figures ${ }^{68}$. Her gesture of one arm down along her side and the other raised from the elbow symmetrically repeats that of the first bird-headed female figure.

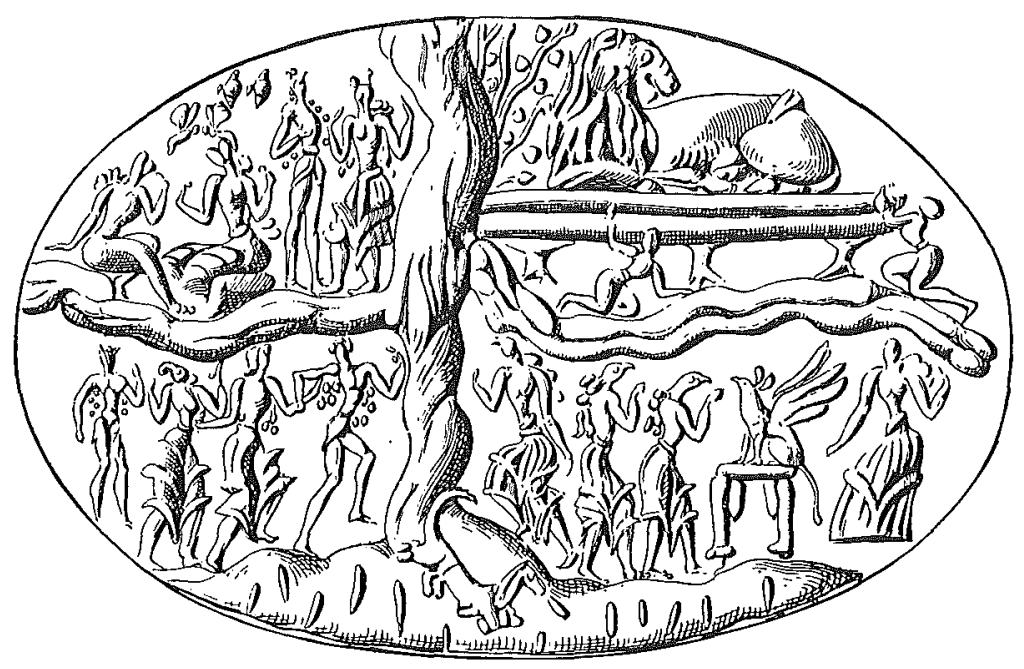

Fig. 5: The 'Ring of Nestor' ( $P M$, III, p. 153, fig. 104)

Evans explains the lower scene as the initiatory examination of those entering the Halls of the Just in the Griffin's Court' ${ }^{69}$. His reading is based on analogy with Egyptian beliefs, and he compares the limbs of the massive tree on the 'Ring of Nestor' with the 'four rivers of Paradise or the triple-branched water course of the Fields of Ialu in the Egyptian 'Islands of the Blest ${ }^{70}$. The composite

67 A. TAMVAKI, The Human Figure in the Aegean Glyptic of the Late Bronze Age: Some Remarks, in CMS (1989), p. 263, 264.

68 But see $P M$, III, P1. XXA, which opts for the former.

69 PM, III, 154.

$70 P M$, III, 147. 
picture reads as one coherent story, according to him, in the fashion of Minoan wall-painting. It is the pictorial representation of the Minoan Afterworld ${ }^{71}$.

Because of its crowded scenes and unusual features, like the large central tree, doubts have been cast on the ring's authenticity ever since Evans published it $^{72}$. Unjustly, however, as it turns out. A curious dog-like creature with short legs, long neck and tail, the forerunner of Cerberus according to Evans ${ }^{73}$, appears to be running down along the roots of the tree. An exact replica of the animal has since been found on a ring which came to light in Mycenae in $\mathbf{1 9 5 4}$ and therefore could not have been known to the presumptive forger ${ }^{74}$. Nevertheless, like the Hagia Triada sarcophagus, the Ring of Nestor remains a unique document which on its own can hardly sustain a theory concerning Minoan afterlife.

In one important respect, however, Evans' suggestions have been vindicated. He rightly explained as symbols of regeneration the pair of butterflies and chrysalises above the 'goddess' head in the ring's upper zone. His detailed digression on the topic and discussion of comparative material from the Third Shaftgrave of Circle A at Mycenae is quite convincing ${ }^{75}$. Recognizably similar designs of winged insects were engraved on the golden scales from the grave which also contained models of bees in gold leaf together with objects in the shape of chrysalises or pupae $e^{76}$. The wonderful miniature golden balance with two scales, which have butterflies engraved on them, call to mind Zeus' golden scales with which he weighed the keres, or fates of death, of Achilles and Hector ${ }^{77}$. Evans thought of the scales as an instrument for weighing the souls of the dead, a kind of $\psi v \chi 0 \sigma \tau \alpha \sigma i \alpha$, again on analogy with Egyptian religion ${ }^{78}$.

The subject has been discussed elsewhere with the conclusion that, on the evidence, a belief in the existence of a soul and its posthumous judgment seemed unlikely in Minoan thought ${ }^{79}$. The sign of the butterfly, bee and related symbols suggests the more basic message of renewal from death and decay. The idea governed ancient religious belief at least since Early Minoan and can ultima-

\footnotetext{
71 Ibid.

72 E.g. NILSSON, $M M R^{2}$, p. 43-50.

$73 P M$, III, 154.

74 CMS I, p. 167. See J.A. SAKELLARAKIS, Über die Ecbtbeit des sogenannten Nestorringes, in Acts of 3rd Cretological Congress (1973), p. 303-318; cf. LAFFINEUR, art. cit. (n. 45), p. 234.

75 PM, III, 149-152.

76 PM, III, 150-151, Fig. 100a, b; Fig. 101, 1-4; Fig. 102.

77 HOM., Il., XXII, 209-213, with LEAF's commentary on this passage and $I l$., VIII, 69, 70.

78 PM, III, 151.

79 B.C. DIETRICH, The Judgment of Zeus, in RbM, 107 (1964), p. 121-122; Fate, op. cit. (n. 6),
} p. $241-242$ 
tely be traced back to neolithic Anatolian Çatal Hüyük ${ }^{80}$. The panel on the Ring of Nestor therefore, at its most basic level, reveals the expectation of new life. The message is of course appropiate for a gift to the dead prince of Messenian Pylos. More one cannot read from the design without forcing the evidence; but it is to be hoped that new information will cast more light on the episodes of the whole story. Certainly the elaborate composition on the ring portrays one or more scenes from Minoan myth and sophisticated religion.

\section{Scenes from Minoan and Mycenaean larnakes}

The sarcophagus at Hagia Triada bridges the divide between neopalatial tradition of wall painting and post-palatial forms that in turn linked up with the Mycenaean world. The figures on the coffin are dressed more in the fashion of the mainland than in the usual Minoan garb of open bodice and skirt ${ }^{81}$. The festival of the dead shown on its sides, as well as other features, have a distinctly Mycenaean 'flavour' ${ }^{82}$, although one would in any case expect common religious forms in the last phases of the Bronze Age. Chronologically the limestone sarcophagus introduces a period of intense interest in funerary art over more than two-hundred years. Many painted stone and clay coffins have turned up in Crete between about 1400, that is the date of the Hagia Triada sarcophagus itself, and 1200 B.C. (LM IIIA - C; most examples date from IIIB) ${ }^{83}$.

In complete contrast with neopalatial frescoes, the decoration of the late larnakes consists in abstract designs which cover the body and lid of the coffins in deceptively simple style. Figures are now far less in evidence, if not altogether absent, and the overall effect recalls the designs and mixed perspectives of vase painting ${ }^{84}$. Contemporary coffins from Tanagra on the mainland mostly show mourning (female) figures in keeping with the purpose of the decoration. The Minoan connection emerges from the continued use of common symbols like horns of consecration, birds etc. ${ }^{85}$. The link with funerary ritual for an individual deceased is obvious in the case of the mainland examples but far less so from

80 DIETRICH, Origins, op. cit. (n. 35), p. 104, 119-122; cf. R. LAFFINEUR, in L'Iconograpbie minoenne (Acts of the Round Table at Athens, 21-22 April 1983), Paris, 1985, p. 250-257.

81 VERMEULE, art. cit. (n. 10), p. 135.

82 See previous note and NILSSON, $M M R^{2}$, p. 441, 442.

83 VERMEUle, ibid; MARINATOS, MinRel, op. cit. (n. 6), p, 229-241, with illustrations.

84 Cf. N. Platon, La civilisation Égéenne, Paris, 1981, II, p. 330, Figs. 29 and 30. On the subject of late larnakes see, apart from PINI, op. cit. (n. 5), B. RUTKOWSKI, Lamaksi Egejski, Warsaw-Krakow, 1966 (Bibliotbeca Antiqua, 7); C. MAVRIYANNAKI, Recbercbes sur les larnakes minoennes de la Crète occidentale, Rome, 1972 (Incunabula Graeca).

85 No double axe, however; VERMEULE, art. cit. (n. 10), p. 126. The Tanagra sarcophagi cannot be compared with Minoan larnakes, according to SOURVINOU-INWOOD, 'Reading' Greek Death, op. cit. (n. 43), p. 40-41, despite their comparable form and age. 
the Cretan abstract designs. There is no evidence, however, that the change in the style of decoration accompanied a fundamental shift in the conception of death and afterlife.
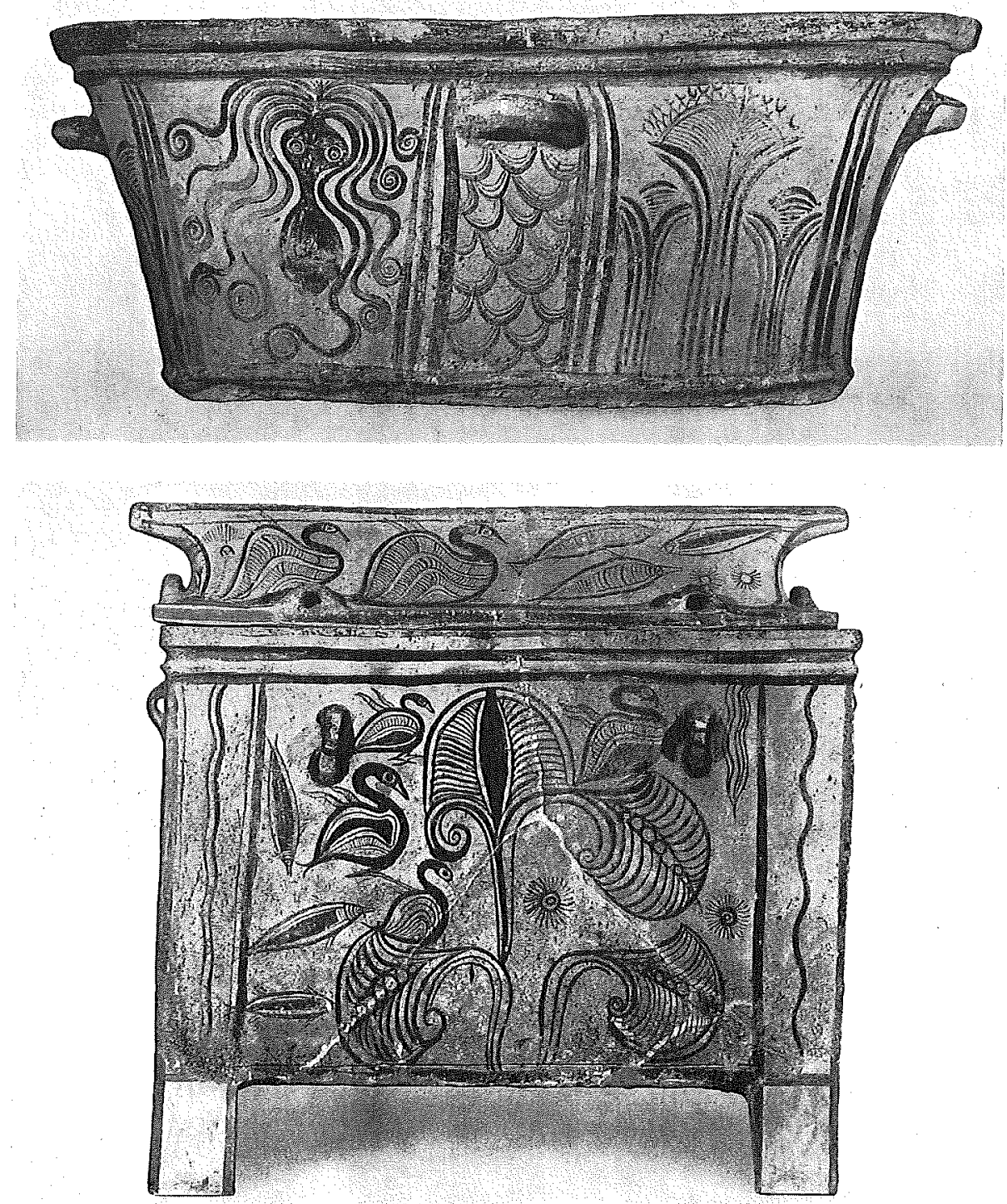

Fig. 6a : Sarcophagus with octopus and papyrus, Pachyammos

Fig. 6b : Sarcophagus with lid, waterbirds and fish (MARINATOS-HIRMER, op. cit. [n. 46], fig. 130) 
The painters of the coffins borrowed from the motifs on vases including papyrus plants, terrestrial animals, bull, horse, goats, creatures of the sea, octopus, fish, nautilus etc. Their sizes vary and can be quite disproportionate to one another as well as to real life on the same coffin. Figures may be zoned off separately, as on a larnax from Pachyammos (Fig. 6) ${ }^{86}$, but generally they are carelessly placed in juxtaposed profusion. A coffin from Anogeia in central Crete has a large central papyrus plant which is surrounded at all levels by birds, fish and other sea creatures. More birds and fish cover the lid ${ }^{87}$. Theme, subject and form closely match those of contemporary small funerary vases (alabastra) from tombs at Kalyvia near Phaistos (Fig. 7), and on a pyxis (jewel box) that was found in a chamber tomb at Pachyammos ${ }^{88}$. The crowded pictures suggest the overwhelming fertility of generous nature in the air, on land and in the sea ${ }^{89}$.

The symbolism conveyed by the paintings is still basic and is repeated on other larnakes. Only occasionally does the evidence afford a glimpse below the surface for a more detailed reading of myth or ritual. The pyxis from Pachyammos, for example, is painted with a large male figure in priestly dress but in the grim style of the time with long neck and one large central eye. He holds a seven-stringed phorminx or lyre, and he appears to be charming birds with his music making them rise from below and dive down from the sky ${ }^{90}$. The story nevertheless does not really depart significantly from the basic context of renewal from death, as is clearly signalled by the two pairs of sacred horns with double axes in the middle.

Horns and axes, together with other related symbols, continue to be favourite themes of funerary art. Chariots also occur not infrequently since the Hagia Triada sarcophagus. They transcend their purely funerary function as bier or part of the procession and could have signalled divine arrival or departure. More commonly a chariot recalls the hunt in this world. It may be shown empty, its horses unyoked and suspended in space as part of a larger scene ${ }^{91}$. Hunting seems to have been the message in the main: either a particular hunt or more commonly, one suspects, the general theme as representing man's noblest and most pleasing pursuit in this world.

A lively scene of the genre can be seen on the sides of a late larnax from Armenoi in western Crete $^{92}$. The hunt is viewed from above. Two horned cattle

\footnotetext{
86 Large octopus with stylised papyrus, Fig. 6a.

87 Fig. 6b.

88 MARINATOS-HiRmer, Kreta, op. cit. (n. 46), Pl. 126-128.

89 Cf. LAFFINEUR, ant. cit. (n. 45), p. 237; MARINATOS, MinRel, op. cit. (n. 6), p. 234.

90 MARINATOS-HIRMER, Kreta, op. cit. (n. 46), Pl. 128 bottom. The authors describe the figure as an early Apollo Kitharodos, p. 150. A scene with Orpheus springs to mind.

91 E.g. on a larnax from Kavrochori, MARINATOS, MinRel, op. cit. (n. 6), Fig. 238.

92 AAA, 4 (1971), p. 217, fig. 4.(MARIN. Fig. 240)
} 
are painted with a spear jutting out of their back at an angle. A man next to one of them strikes his victim with a sword. A very similar scene covers one of the narrow ends of a coffin from Maroulas ${ }^{93}$. The victims are horned cattle and goats. Hatched loops on both larnakes can be read as entrances to caves as seen from a bird's eye view. A good example survives on a vase from Phaistos in the Kamares-style, on which a cave and goat have been moulded in relief ${ }^{94}$. Despite spear and sword, the ambience of the hunt is surprisingly peaceful, since on the Armenoi coffin the animals are protecting young beneath them that appear to be suckling. The symbolism of renewal through life-giving nature again emerges from the scene and is reinforced, one imagines, by the male figure, perhaps a priest, who is standing in the mouth of a cave wielding what appears to be a double axe in his raised hand ${ }^{95}$. The ultimate message of this generic picture is still the same, including sacrifice/slaughter, cave and double axe.

The most remarkable example of the series comes from a cemetery in Hierapetra in south-eastern Crete. Four clearly outlined panels contain more human figures than other larnakes, as well as the largest among them ${ }^{96}$. Bottom left depicts three men standing in a curious boat-shaped chariot which is drawn by a horse from left to right. It stands above a large octopus. The occupants of the wagon carry a cup and a disk fixed to a staff. The impression of a ritual procession is reinforced by three more male figures above the chariot group with raised arms and moving in the same direction. One of them is also carrying a drinking vessel. On the right bottom panel the largest male figure holds a similar disk and cup in his raised hand. He is shown frontally beside a horse to which he is attached by a string. A young foal stands beneath the horse suckling, like the animals on the Armenoi larnax. The lid of the coffin on both sides has more animals in a similar arrangement, except that other smaller ones are shown above their backs as well. A remarkable feature of the composition consists in the curious excrescence between the horns of one large animal standing before a human figure ${ }^{97}$. The other side is almost equally filled with large and smaller human figures together with animals and plants. One small male figure between the two bottom panels on the first side somehow links the various panels of the extraordinary larnax. Its one side suggests the paraphernalia and ritual of a funerary procession, the other less certainly a scene from nature, a hunt perhaps, although no one can tell for sure. The single eye, which is almost as big as the

$93 A A A, 6$ (1973), p. 319, fig. 3.

$94 \mathrm{MM}$, from the first palace of Phaistos.

95 For a different view, with full discussion, see PöTSCHER, Aspekte, op. cit. (n. 3), p. 20, 32, fig. 3.

96 MARINATOS-HIRMER, Kreta, op. cit. (n. 46), Pl. 132.

97 Cf. the animal on the left on a larnax from Gournia, MARINATOS-HiRmer, Kreta, op. cit. (n. 46), Pl. 131. 
head of individual men (there are no females), graphically expresses light and life; but this also remains an inspired guess like so many others on the subject ${ }^{98}$.

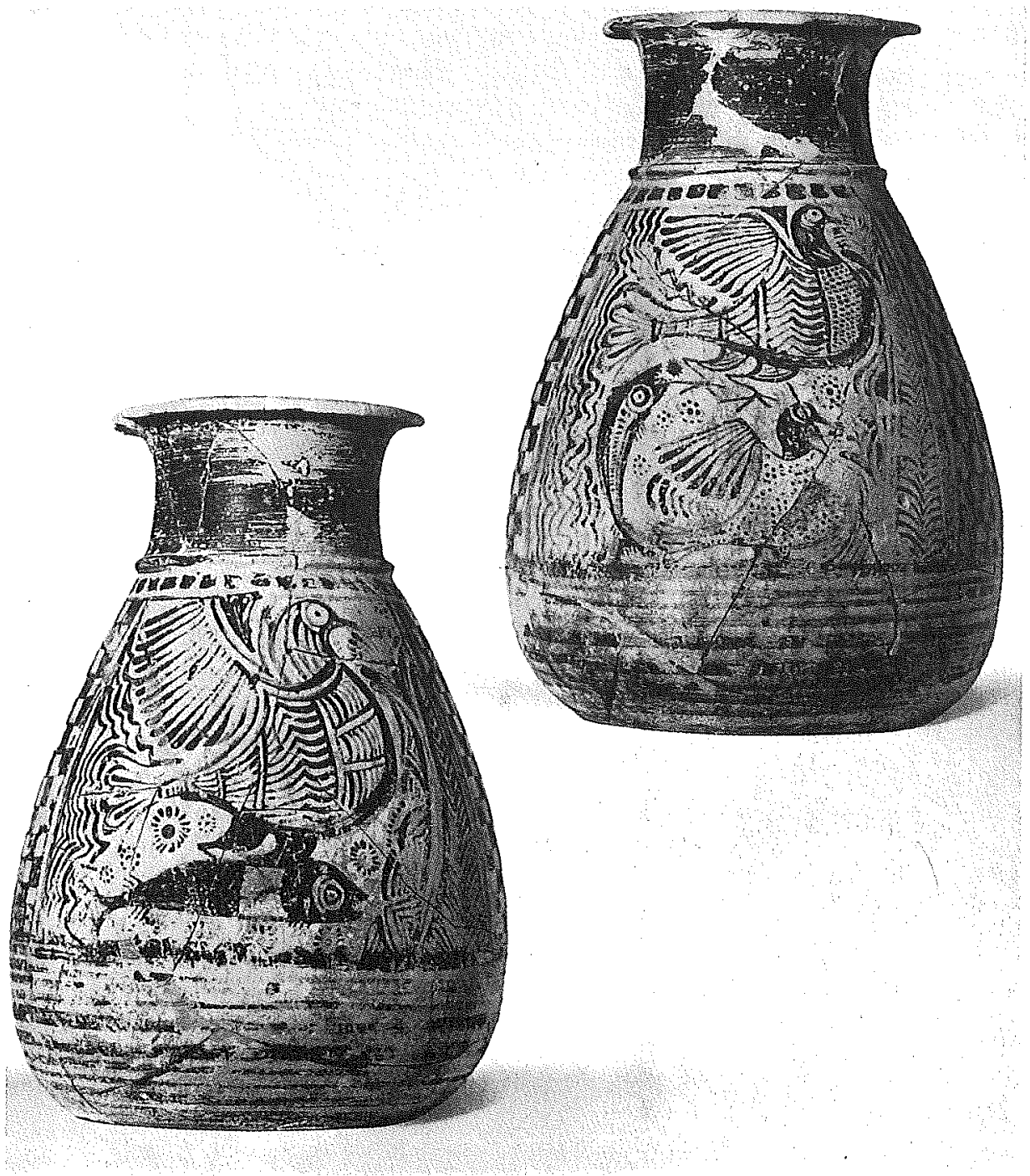

Fig. 7 : Alabastra from Kalyvia (MARINATOS-HIRMER, op. cit. [n. 46], fig. 127)

98 E.g. hunt: PLATON, op. cit. (n. 64), p. 330; adoration of a divine bull, p. 362 ; komos: MARINATOS-HIRMER, Kreta, op. cit. (n. 46), p. 152; the dead as Master of Animals: MARINATOS, MinRel, op. cit. (n. 6), p. 237, etc. 
The contemporary larnakes from a Boeotian cemetery at Tanagra, look like crude local productions beside the island models. Few have lids or handles 99 : they are heavy clay boxes with faded, thin and patterned-type decorations. These mostly consist of women mourning the one dead of that particular burial. For all that, the designs retain important elements of the same vocabulary of funerary symbols: plant and horns of consecration whose meaning doubtless repeated the same message of renewal ${ }^{100}$. The mainland community, that was served by the cemetery, was evidently poor and could not match the quality of artists and resources of Crete. The Tanagra coffins, however, show the same mix of Minoan/Mycenaean burial customs as the Mycenaean shaft graves in the rectangular enclosure at Phourni near Arkhanes ${ }^{101}$. The chamber tombs at Tanagra had long entrance passages (dromoi) Up to three larnakes were deposited inside one tomb ${ }^{102}$, some containing bones, while in other cases the bones were found directly on the ground. Perhaps they belonged to earlier burials and had been cast aside; but larnakes were not part of the usual Mycenaean burial practice in shaft or chamber tomb, and their use in these settings was borrowed from Minoan form.

One coffin of the Tanagra group, and now in the museum at Kassel in Germany ${ }^{103}$, offers something excitingly new that seems to confirm both Minoan and Mycenaean pragmatic perceptions of human fate after death. On one of the small sides, between two strips of chequerboard pattern and below circular beam-ends denoting an enclosed structure, a female figure is painted in fading outline. Her feet are off the ground, and with arms upraised she seems to be floating upwards on two wings sprouting out of her sides. Her plumed flat cap vaguely recalls that worn by the sitopotinija (?) of the Cult Centre at Mycenae ${ }^{104}$. There is a certain similarity in her attitude of raised arms and wings to a later figure on a Protogeometric funerary pithos from the Fortetsa cemetery near Knossos ${ }^{105}$. At first glance the latter could be mistaken for a survival of the Minoan iconographic type; but her attachments to the waist are in fact snakes which, not unusually for the period, she probably owed to oriental models. She

\footnotetext{
99 VERMEULE, art. cit. (n. 10), p. 125.

${ }^{100}$ Vermeule, art. cit. (n. 10), Pl. XXV-XXVII. The author suggests (p. 145) that the horns, which appear on two coffins ( $\mathrm{N}^{\circ} 5 \& 8$ ), are mere architectural patterns devoid of religious content. Given the close chronological and cultural links, this seems unlikely, however.

101 Above n. 11.

102 VERMEUle, ait. cit. (n. 10), p. 125.

${ }^{103}$ R. LuLLIES, Griechische Plastik, Vasen und Kleinkunst, Kassel, 1964, $\mathrm{n}^{\circ}$ 37; VERMEULE, art. cit. (n. 10), p. 126-129; 146; Pl. XXVI a, b.

${ }^{104} \mathrm{P} . \mathrm{REHAK}$, Tradition and Innovation in the Fresko in Room 31 in the 'Cult Center' at Mycenae, in Aegaeum, 8 (1992), p. 56 \& Fig. XIIa.

105 Fortetsa pls. 24 \& 144 n ${ }^{\circ} 339$; COLDSTREAM, Geometric Greece, p. 69, Fig. 21 a, b; VERMEULE, art. cit. (n. 10), Fig. 2(e).
} 
may be a goddess ${ }^{106}$, but not so the winged, waif-like form on the Tanagra larnax. The latter looks more like a somewhat clumsy attempt at pictorial representation of the deceased's eidolon on its way to Hades. If that is right, the singular coffin reflects the negative contemporary view of afterlife which Homer adopted in his epic ${ }^{107}$.

B.C. DIETRICH

ABERYSTWYTH

UK

106 Coldstream, op cil. (n. 105), p. 70, thinks of the divine protector of the deceased in the underworld.

107 This plausible interpretation was first proposed by VERMEULE, art. cit. (n. 10), p. 146-147. 